\title{
Principals' Reflections on Effectively Managing Their Schools: Cooperative Leadership and Its Role in Schools
}

\author{
Çağda Kıvanç Çağanağa \\ Faculty of Education, European University of Lefke, Lefke, Cyprus \\ Email:ckivanc@eul.edu.tr
}

Received 22 October 2015; accepted 7 November 2015; published 12 November 2015

Copyright (C) 2015 by author and OALib.

This work is licensed under the Creative Commons Attribution International License (CC BY). http://creativecommons.org/licenses/by/4.0/

(c) (i) Open Access

\begin{abstract}
Despite widespread and long-standing commitment to the notion of leadership across the teaching profession, it is unusual for the theory and practice of leadership to be taught as a subject in education. This study examined what factors the participants believed influenced their school management approach and how they defined their current leadership styles. This paper offers theoretically informed models of leadership which encompasses different purposes (assessment of self and the school system). Finding out the leadership styles of the principals helps them find ways to understand complex educational issues. Available literature points to the realization that there have been few studies that explore principals' perceptions of the factors underpinning their successes and achievements. A qualitative research project was undertaken in Cyprus by using indepth interviews. Data were collected from interviews. Journal entries were also analyzed for the benefit of the study. Microanalysis was used to analyze the data and cross case analysis was used to look for similarities and differences between the cases. Analysis was informed by movement between theoretical dimensions and emerging themes from participants' discussions of their leadership experiences. This research has shown that the participants had similar goals with regard to their school management yet implemented it in different ways. This study illustrates implications for future research on the factors influencing school management.
\end{abstract}

\section{Keywords}

Leadership Styles, Personal Mastery, Cooperative Leadership, Critical Reflection

Subject Areas: Education

\section{Introduction}

We have always had leadership, even if we did not call it that. Like everything else, schools and their leadership

How to cite this paper: Çağanağa, Ç.K. (2015) Principals' Reflections on Effectively Managing Their Schools: Cooperative Leadership and Its Role in Schools. Open Access Library Journal, 2: e1962. http://dx.doi.org/10.4236/oalib.1101962 
challenges have been changing rapidly in recent years, and educators and school principals have been running hard to keep up. Leadership is an ancient term which was found in recorded discussions in early Greek writings such as Socrates, Aristotle and Plato. They had had theoretical debates about the one and the many. This was the basic question of leadership: how do we interface with others? This paper draws together multiple interpretations and uses of leadership styles and critical reflection from the broad fields of education and professional development to develop a more defined language and theory base.

Research on school leadership and principals increasingly suggests that effective management of schools is reliant on the personal mastery. The description of personal mastery that has attained the highest level of visibility over the years is that by [1]-[4] who call it "personal vision", the results you most desire and the person you want to be [1]. It is very important for the principals to see the current reality clearly. It is a prerequisite which is as important as developing a clear vision [1]. Personal Mastery is one of the five learning disciplines first promulgated by Peter Senge who popularized the term-learning organization, in his 1990 ground-breaking book, The Fifth Discipline. Knowing where you are in your career or your priorities and objectives is major indicators of your success and behaviour as they form the framework for personal mastery. Recent theoretical work has also sought to increase the clarity concerning the key contributors to personal mastery [5]. As discussed by [5] that personal values (which direct personal commitment to development); motivation (a person with high personal mastery would be self-motivated); individual learning; personal vision; and finally development and training are the essential components of personal mastery. Blackman and Henderson's case studies add support to motivation being critical to personal mastery [6]. Finally, [5] argues that human resource policy also plays a role in facilitating personal mastery with most organizations focusing on professional rather than personal development.

The personal mastery literature shows the numerous positive effects of it on educational leadership. With regards to leadership generally, Senge suggests, "the core of leadership strategy is simple: be a model. Commit yourself to your own personal mastery” [1]. Personal mastery has been studied most frequently in the context of personal growth. It was claimed that "the real power centers within an organization were the interpersonal relationships that developed among working groups" [7].

Today, scholars in the field of leadership [1] [8]-[14] have advocated the importance of knowing oneself and the commitment to lifelong learning as an essential element in the discipline of leadership. Self-awareness is "an emerging process where one continually comes to understand his or her unique talents, strengths, sense of purpose, core values, beliefs and desires" [15].

Personal mastery equals to self-awareness. It's "the discipline of personal growth and learning" says Senge, but it entails more than just learning new skills. It's "the discipline of personal growth and learning”, says Senge, but it entails more than just learning new skills. With personal mastery, personal purpose and vision come first-it starts by clarifying what really matters most to us. At this point, a broader link between personal mastery and critical reflection needs to be made to turn the mirrors inwards. Personal mastery involves, as Senge says, a "commitment to truth—a relentless willingness to uncover the ways we limit and deceive ourselves". [16] defined "reflection" as thinking about what we were thinking, acting upon rather than reaction to a stimulus. [17] argued that "Reflection is a way of helping practitioners to better understand what they know and do as they develop their knowledge of practice through reconsidering what they learn in practice". Reflection is a crucial component of reviewing one's practice and "taking time to step back and to ponder the meaning of what has happened, the impact of it and the direction one is taking” [18]. As a systematic and purposeful methodology for examining ones' own practice, reflection makes it possible to understand and resolve conflicting situations and expectations through inquiry [19] [20]. There is a close relationship between critical reflection and personal mastery because both support the idea that understanding the self is crucial for the transformation to self-direction progresses. [21] argues that critical reflection is held as a way of examining our own subjective thoughts about who we are. A social theory perspective of critical reflection is that it allows us to examine the uniqueness of our individual positionality within social systems [22] [23]. This could mean looking at how we align ourselves with particular identities (mother, father, doctor, nurse, patient, etc.) or how these identities encourage us to act in certain ways. Reflective knowing reflects on established professional steretypes or practices. [24] states that "Critical reflective knowing is neither behavioural nor technical, not truth establishing nor captured by a discipline. It critiques all other forms of knowledge, and in so doing, it moves beyond merely reproducing what is" (p. 42).

In the context of education, critical thinking has been perceived as a way of improving professional practice rather than simply recreating professional knowledge [25]. Similar to the critical thinking, personal mastery 
concerns issues of how self actualisation is created and how it is directed towards political and ethical goals.

As this study discusses the school management approach of two primary school principals, it will note evidence of leadership styles - we no longer believe that one administrator can serve as the instructional leader for an entire school without the substantial participation of other educators [26]-[31]. The old model of formal, oneperson leadership is no longer effective in school settings. For a sustainable school improvement principals have to meet the fundamental challenge of providing quality learning for all students. In this vein, leadership, which can be named as cooperative leadership, has to be the professional work of everyone in the school. This kind of leadership has four dimensions which can be summarized as follows.

1) Mutual participation: All leaders in the school settings have some types of power and they desire to see lives transformed. The comparison between power and participation actually shows the numerous positive effects of cooperative leadership compared to the numerous negative effects associated with power. The need to do away with power distribution in the management of schools has to be seriously considered by principals. Not only principals but also teachers and students assist in ensuring that taking responsibility for making good decisions and why those decisions are in their beat interest. It is important for principals to have at least the following personal values and skills, which will enable them to encourage and foster active participation: humility, the ability to relinquish the role of the expert, an awareness of their position of power and the ability to value other participants' role in the school setting.

2) Shared vision and mission: [32] argues that determining the clarity of vision and mission in an organization is important in order to prevent the lack of performance of the organization itself. Clear vision and mission are the key elements of high-performing organizations and teams. A vision states what the organization aspires to be or become in the future. It identifies what the leadership deeply cares about and what the organization looks like when the vision is achieved. How the organization is going to operate in order to fulfill the vision is the mission which is the roadmap that guides us as we travel there.

3) Reflective practice: Strategic thinking and reflection is a crucial aspect of leadership in schools. At primary level, school leaders are much more involved in the day-to-day running of the school. So, how can primary school principals effectively bring more strategic and reflective thinking into their already busy schedules? Reflection does not have to be solitary.

But it does need to be focused on school improvement, whether that's on raising standards, improving the wellbeing of staff or other areas you may wish to develop.

4) Inquiry based learning and teaching: Inquiry-based learning is an approach to teaching and learning that places students' questions, ideas and observations at the centre of the learning experience. Inquiry actually starts with a leader or principal in schools as they engage learners and teachers with the foundational belief that learning is a life long journey and many things are being waited to be explored.

It can be concluded from the above discussion that there are four salient dimensions of leadership in educational contexts. Literature has identified and described many definitions and approaches to leadership. A new concept or term can be added to the literature to fulfill the demands of today's concept of leadership. The position gives the principal or the leader the ultimate authority in making behaviour guidelines and deciding on consequences and rewards.

The choice of sharing the responsibility is the essence of the new term-cooperative leadership. Since the above mentioned qualifications of a leader can play an important role in managing schools, it is important to understand the power of cooperation. Through this new approach, the principal or the leader is expected to create a positive relationship among both the staff and the students. This model of leadership upholds the importance of considering the emotional and individual needs of the staff. It also highlights collaboration and cooperation within the school or institution. Leadership or managing a school is a long journey and during the journey the leader or the manager is required to have a rest at certain stops to update or refresh him/her. In other words, s/he should reflect critically on himself/herself. With the constant emphasis on cooperation as being a critical component to the success of principals, there is still a need for further study to negotiate and define school management.

\section{Methodology}

The focus of this qualitative study is to examine experienced primary school principals' reflections on effective school management. The study aims to use the qualitative constructivist theoretical perspective to examine 
"what the participants' reported perceptions, truths, explanations, beliefs, and worldview are” [33]. The participants of the study which will be mentioned by their nicknames were selected through purposeful sampling to show the reflections of two exemplary primary school principals. They were selected because their colleagues and students had described Mary and John as being effective principals. They selected purposeful sampling [33] to show the reflections of two exemplary English teachers. They both started to manage schools 15 years ago and both have worked for the ministry of education in Cyprus for a longtime. Both of them openly talk about their views of school management. John, a Cypriot male with 15 years of management experience, manages a traditional primary school that belongs to the state which has 100 students from different parts of the island. His school is in one of the poor rural areas of the island. Mary, a Cypriot female with 10 years of management experience, manages a traditional primary school that belongs to the state which has 80 students from different parts of the island in urban setting.

This study addresses the following research questions: (a) explain your management philosophy that guides your management style in your role as principal and (b) can you provide critical incidents that illustrate your espoused management philosophy? In addressing these questions, I examined the themes that arose as principals described their beliefs about school management and their current school management approach.

\section{Data Collection and Analysis}

Data collected for this study included interviews and informal conversations. Two primary school principals from the ministry of education in Cyprus participated in the study. Interview question items were designed in such a way that they gave room for fur their probing and prompting. All interview proceedings were planned to be audio taped and later transcribed by the researcher. The questions in the interview form; explain your management philosophy that guides your management style in your role as principal, can you provide critical incidents that illustrate your espoused management philosophy?, tell me about the school management skills that you currently implement in your schools? How do you feel about your school management abilities? Which personality traits that you possess do you believe will contribute to your success with certain school management practices? And why? Can you describe your school management approach? What factors influence your school management practices in order to determine the underlying causes of the participants' answers, interview questions are arranged during the 70 minutes interviews? Every opinion expressed by the participants is discussed in detail. To probe deeper into the main research questions, the participants were also given the opportunity to discuss the following sub-questions: How do you deal with discipline problems? Do you think you improved yourself in your profession? A healthy environment based on trust and empathy was tried to be created by the researcher in order for participants to express their opinion freely and reflect their feelings comfortably. Participants were informed that their personal and professional information would be kept secret, their ideas and suggestions would be used by giving a nickname to create a positive researcher participant relationship.

The findings of this study are the results of the cross-case analysis. According to [34] cross-case analysis is a research method that facilitates the comparison of commonalities and difference in the events, activities, and processes that are the units of analyses in case studies. (See Table 1) The findings in this study are the result of the crosscase analysis. The teachers' reflective discourse via interview transcripts were used to explore the participants' view of their school management practice. In this study, qualitative research reliability was used for the purpose of generating understanding of the value of principals' responsibilities and reflective practice in school management. Validity was established by utilising quality, rigour and trustworthiness, for the purpose of establishing confidence in the findings [35]. Credibility of the study was enhanced by using a case analysis. [36] argues that credibility was done “.. by using one or more of the following strategies: prolonged engagement, persistent observation, triangulation, peer debriefing, negative case analysis and/or member checking”. Confirmability, on the other hand, involves ".. the use of written field notes, memos, a field diary, process and personal notes, and a reflexive journal [36]”.

With the help of micro analysis participants' words from the interview transcripts and journal entries were coded for initial categories to emerge and be defined [37]. Categories and subcategories were reviewed to search for internal and external homogeneity among the categories. Themes that emerged related to factors influencing school management were mutual participation, shared vision and mission, reflective practice, and inquiry based learning and teaching. Shared responsibilities, having positive relationships, emotional and individual needs of the staff are the definitions of participants regarding their school management approach. 
Table 1. Cross-case analysis themes for Mary and John.

Factors influencing school management

Factor Types

Mutual Participation Cooperation

Shared Vision and Mission Seeing Personnel as Individuals

Reflective Practice Establishing a Comfortable Environment

Inquiry Based Learning and Teaching Authority

Defining Their School Management Approach

Cooperative Leadership Examples

Shared Responsibility John focused on small groups to dedicate the jobs

Having Positive Relationships Marry considered personal issues

Emotional and individual needs of the staff John gave importance to staff development

\section{Findings}

The findings of the study focused specifically on the principals" belief about personal mastery and their leadership approach to managing their schools. In this study, qualitative data analysis involved breaking the information into manageable themes, patterns, trends, and relationships [38]. This section is organized according to the research questions guiding this study: (a) what factors influence their school management practices? and (b) how do these principals describe their school management approach? Participants noted two factors that influenced their school management approach - the leadership types of them and being a reflective practitioner as a principal. The following section will discuss how these two themes influenced participants ${ }^{\text {ee }}$ school management. The two paradigms which influence principals" school management are their personal mastery and leadership styles.

\subsection{Personal Mastery}

As noted above personal mastery is the personal vision that directly impacted teachers, students, and their learning. These visions were ones that John and Mary imposed on themselves and believed were crucial to being an effective principal and managing their schools. When reflecting on their school management, John and Mary examined issues related to their leadership styles and how it influenced teachers, students and their learning. In discussing these issues, four categories emerged: 1) mutual participation; 2) shared vision and mission; 3) reflective practice; 4) inquiry based learning and teaching.

\subsection{Mutual Participation}

Mutual participation in schools can be developed as part of strategies providing assistance for teachers, students, and principals. This kind of participation can also be used to provide support for innovation and professional development. Of course such participation offers a useful strategy for enhancing staff involvement with a school. Both principals were aware of the different backgrounds and the needs of their staff. Mary noted: "my staff differ in ability, maturity, motivation, commitment, etc. They are different from me”. Both John and Mary used their understanding of their staff to determine how they organize and implement their schools. Mary wanted to provide her staff opportunities to talk and collaborate with their colleagues. She says "I try to understand my staff, deal with their problems, I mean, they have opportunities to share their ideas, feelings etc." Mary placed a lot of value on giving her staff a forum to express their opinions and feelings. When she talked with them, Mary would ,try to have dialogue that indicated to them that they are welcome to express their opinions and even if I disagree with them, it's okay for them to have a belief that's different from mine”. Mary organized her school to reduce opportunities for the staff to be excluded. In addition, she provided time for the staff to receive one-toone support from her and enhance staff motivation and engagement in the school. Likewise, John had a strong 
understanding of personal vision and how staff reacts to certain decisions. John stated: "due to my experience in the teaching profession, I know what steps and strategies the principals are going to struggle with and so I am able to solve the problems before they occur”. John tried to identify the problems that he thought might be confusing to the staff. Both Mary and John combated school management issues by using their experience. They believe that equality is the key term in leadership. Mary, as well as John made a point of distributing equal responsibilities to each staff and make them use this responsibility to guide an inviting school environment. By creating a comfortable school environment they were able to make their staff feel safe and relaxed. Mary stated: [the most important thing is] having an environment, you know, where my staff is relaxed and comfortable, success comes after. We are like a family. I am like their big sister. Everyone is equal. I usually dedicate a person for a job. In order for principals to be viewed as authority figures, John and Mary believed they needed to use certain strategies to relay their position to the staff. Mary says; [At the beginning of the semester] we have a meeting and we discuss the issues from A to Z. Everyone knows that we are professionals. No one takes what I say personal. The big thing about management or leadership is having the ability to say „no“. The goal of my management approach is to avoid public confrontation. I prefer one-to-one conversations. If I were one of them, I would prefer that way.

\subsection{Shared Vision and Mission}

John, like Mary believed in showing the staff that he has a vision in and outside of school and that he wanted to share it with his staff. He cares about the staff and the students. By making this explicit to their staff and the students, John and Mary attempted to help them focus on creating a school vision and mission. To further aid in staff's enjoyment of their school and create positive interactions, both participants readily used humour in their schools. They believed that dealing with the problems of the staff allowed them to appreciate the "human" side of the principal.

\subsection{Reflective Practice}

Many researchers have investigated the benefits of reflective thinking and reflective practice for school administrators [39]-[44]. The explanation of school administrators"e failure or success in managing intentional changes in their schools depends on their way of thinking. Therefore the first thing to do in a school in order to change the attitudes and behaviours of administrators and other educators is to change their way of thinking [45]. Although there is a Teacher Training Head Office under the Ministry of National Education there is not a unit for training school administrators. Therefore on-the-job learning is very crucial for school administrators. Reflective practice was also conceptualized as a professional development and problem solving strategy [46], therefore reflection is very critical in the teaching, leadership and learning processes of educators [16] [44] [47]. Both Mary and John constantly tried to pay attention to their personal relationships, interpersonal issues, and contextual factors influencing what is said or done. John stated: "I frequently think about what I say or do. I try to empathize my colleagues”.

\subsection{Inquiry Based Learning and Teaching}

[47] calls for school leaders to be actively involved as leading learners. They argue that the more leadership is focused on the core business of teaching and learning, the greater its impact. [48] argues that a necessary condition for school leaders' success in the future will be their capacity to improve the quality of instructional practice, a position that places inquiry into the impact of teaching on learning at the centre of their professional development. [47] also calls for school leaders to be actively involved as leading learners. They argue that the more leadership is focused on the core business of teaching and learning, the greater its impact. Both John and Mary did not view inquiry based learning and teaching as unimportant or unnecessary. Mary stated: "Learning is a lifelong process. I can learn from anyone, even from a worker who is not educated".

\subsection{Leadership Styles}

The central concern in this paper-educational leadership—-has been studied most frequently in the context of school management. Both Mary and John stated that experience is the key point in leadership. This is explained by John as: When I took over ten years ago, I was trying to gain the status of an "autonomous leader". I did look 
into areas that require improvements to meet the criteria of becoming an "autonomous” leader. For four years, I pursue a collective effort, I mean, the school is not only mine, it's ours. It belongs to us. Mary, like John, believed in the importance of experience. Her school management approach is based on sharing and democracy. She noted: The big thing about school management in terms of the responsibility component is staff participation. Everyone is in charge of something. I leave no one out. If everyone is dealing with something, they will have no time to criticize. The idea of authority is connected with the job, I believe. Whoever knows what s/he is doing, is in authority.

\section{Conclusion}

Mary and John realized that their interactions with the staff through their school management approach greatly impacted their behaviour. They created a collaborative school environment where everyone was treated democratically and equal. While their approaches differed, they both identified their approaches as being successful. Both also noted the drawback of being identified as an effective principal by their attitude towards their staff. Being equal and democratic helps them to ensure unity in school. Although John only slightly used elements of a collective attitude in most of his career, he realized the importance of it later on in his career. Both he and Mary were able to appropriately navigate the continuum of school management approaches.

\section{Implications}

Successfully managing a school is crucial to the success of both students and teachers. In leadership, it is also crucial to the understanding of processes and skills need for the implementation of effective school management approaches (e.g. cooperative leadership). Research on principals' beliefs and practices in leadership will help them determine what experiences and knowledge included in the school management and professional development will best facilitate principals' development of school management skills. Further research on the influences of personal mastery of principals, such as 1) mutual participation; 2) shared vision and mission; 3) reflective practice; 4) inquiry based learning and teaching noted in this study, can provide an understanding of how school principals are supported in effectively managing their schools. The results of this study would be of value to teacher educators and school principals for they illustrate the need for staff support. Findings from this study also provide insight for school principals on a new kind of management skill, as it is named as cooperative leadership. It suggests the need for more staff participation in order to continue to examine links between management style and personality traits of the principals.

\section{References}

[1] Senge, P.M. (1990) The Fifth Discipline: The Art and Practice of the Learning Organization. Doubleday, New York.

[2] Garcia-Morales, V.J., Llorens-Montes, F.J. and Verdu-Jover, A.J. (2007) Influence of Personal Mastery on Organizational Performance through Organizational Learning and İnnovation in Large Firms and SMEs. Technovation, 27, 547-568. http://dx.doi.org/10.1016/j.technovation.2007.02.013

[3] Bui, H. and Baruch, Y. (2010) Creating Learning Organizations in Higher Education: Applying a Systems Perspective. The Learning Organization, 17, 228-242. http://dx.doi.org/10.1108/09696471011034928

[4] Blackman, D. and Henderson, S. (2005) Why Learning Organizations Do Not Transform. The Learning Organization, 12, 42-56.

[5] Hersey, P., Blanchard, K.H. and Johnson, D.E. (2001) Management of Organizational Behavior: Leading Human Resources. 8th Edition, PrenticeHall, Inc., Upper Saddle River.

[6] Cashman, K. (1998) Leadership from the Inside out: Becoming a Leader for Life. Leadersource, Minneapolis.

[7] Fritz, R. (1999) The Path of Least Resistance for Manager: Designing Organizations to Succeed. Berrett-Koehler, San Francisco.

[8] Anderson, D. and Ackerman Anderson, L.A. (2001) Beyond Change Management. Jossey-Bass, San Francisco.

[9] Huber, N. (1998) Leading from within: Developing Personal Direction. Krieger, Malabar.

[10] Hutchens, D. (2000) The Lemming Dilemma: Living with Purpose, Leading with Vision. Pegasus Communications, Waltham.

[11] Secretan, L. (2006) One: The Art and Practice of Conscious Leadership. The Secretan Centre, Toronto.

[12] Gardner, W. and Avolio, B. (2005) Can You See the Real Me? A Self-Based Model of Authentic Leader and Follower 
Development. The Leadership Quarterly, 16, 343-372. http://dx.doi.org/10.1016/j.leaqua.2005.03.003

[13] Schön, D.A. (1983) The Reflective Practitioner: How Professionals Think in Action. Basic Books, New York.

[14] Loughran, J.J. (2002) Effective Reflective Practice: In Search of Meaning in Learning about Teaching. Journal of Teacher Education, 53, 33-43.

[15] Higgins, D. (2011) Why Reflect? Recognising the Link between Learning and Reflection. Reflective Practice, 12, 583584. http://dx.doi.org/10.1080/14623943.2011.606693

[16] Richardson, V. (1994) Conducting Research on Practice. Educational Researcher, 23, 5-10. http://dx.doi.org/10.3102/0013189X023005005

[17] Weiss, E.M. and Weiss, S.G. (2001) Beginning Teacher Induction (Report No. EDO-SP-1999-3). ERIC Document Reproduction Service No. ED436487, Office of Educational Research and Improvement, Washington DC.

[18] Blaesi, S. and Wilson, M. (2010) The Mirror Reflects Both Ways: Action Influences Perception of Others. Brain \& Cognition, 72, 306-309. http://dx.doi.org/10.1016/j.bandc.2009.10.001

[19] Foucault, M. (1982) The Subject and Power. Critical Inquiry, 8, 777-795. http://dx.doi.org/10.1086/448181

[20] Giddens, A. (1976) New Rules of Sociological Method. Hutchinson, London.

[21] Habermas, J. (1978) Knowledge and Human Interests. 2nd Edition, Heinemann, London.

[22] Barnett, R. (1994) The Limits of Competence, Knowledge, Higher Education and Society. SRHE and The Open University Press, Buckingham.

[23] Elmore, R. (2000) Building a New Structure for School Leadership. The Albert Shanker Institute, Washington DC. www.shankerinstitute.org/Downloads/building.pdf

[24] Lambert, L. (1998) Building Leadership Capacity in Schools. ASCD, Alexandria.

[25] Lambert, L., Walker, D., Zimmerman, D., Cooper, J., Lambert, M., Gardner, M. and Ford-Slack, P.J. (1995) The constructivist leader. Teachers College Press, New York.

[26] Olson, L. (2000) Principals Try New Styles as Instructional Leaders. Education Week, 20. http://www.edweek.org/ew/vol-20/09thiswk.htm

[27] Poplin, M. (1994) The Restructuring Movement and Voices from the Inside: Compatibilities and İncompatibilities. Seminar Conducted at the Meeting of the Association of California School Administrators, Palm Springs.

[28] Spillane, J., Halverson, R. and Diamond, J. (2001) Investigating School Leadership Practice: A Distributed Perspective (Research News and Comment). Educational Researcher, 30, 23-28. http://dx.doi.org/10.3102/0013189X030003023

[29] Hishamudin, H. (2010) Learning Organisation Elements as Determinants of Organisational Performance of Non-Profit Organisations (NPOs) in Singapore. International NGO Journal, 5, 117-128.

[30] Patton, M.Q. (2003) Qualitative Research and Evaluation Methods. Sage Publications, Thousand Oaks.

[31] Khan, S. and Van Wynsberghe, R. (2008) Cultivating the Under-Mined: Knowledge Mobilization through Cross-Case Analysis. Forum: Qualitative Social Research, 9, 1-21.

[32] Davies, D. and Dodd, J. (2002) Qualitative Research and the Question of Rigor. Qualitative Health Research, 12, 279289. http://dx.doi.org/10.1177/104973230201200211

[33] Stenbacka, C. (2001) Qualitative Research Requires Quality Concepts of Its Own. Management Decision, 39, $551-555$. http://dx.doi.org/10.1108/EUM0000000005801

[34] Denzin, N.K. (1994) The Art and Politics of İnterpretation. In: Denzin, N.K. and Lincoln, Y.S., Eds., Handbook of Qualitative Research, Sage, Thousand Oaks, 500-515.

[35] Strauss, A. and Corbin, J. (1990) Basics of Qualitative Research: Grounded Theory Procedures and Techniques. 2nd Edition, Sage, Newbury Park.

[36] Mouton, J. (2001) How to Succeed in Your Master's and Doctoral Studies: A South African Guide and Resource Book. Van Schaik, Pretoria.

[37] Dana, N.F. (2009) Leading with Passion and Knowledge: The Principal as Action Researcher. Corwin \& American Association of School Administrators, Thousand Oaks.

[38] Hart, A.W. (1990) Effective Administration through Reflective Practice. Education and Urban Society, 22, $153-169$. http://dx.doi.org/10.1177/0013124590022002003

[39] Leithwood, K.A., Jantzi, D. and Steinbach, R. (1999) Changing Leadership for Changing Times. Open University Press, Buckingham.

[40] Raelin, J.A. and Coghlan, D. (2006) Developing Managers as Learners and Researchers: Using Action Learning and Action Research. Journal of Management Education, 30, 670-689. http://dx.doi.org/10.1177/1052562905285912 
[41] Short, P.M. and Rinehart, J.S. (1993) Reflection as a Means of Developing Expertise. Educational Administration Quarterly, 29, 501-521. http://dx.doi.org/10.1177/0013161X93029004006

[42] York-Barr, J., Sommers, W.A., Ghere, G.S. and Monthie, J. (2006) Reflective Practice to Improve Schools: An Action Guide for Educators. Corwin Press, Thousand Oaks.

[43] Osterman, K.F. and Kottkamp, R.B. (2004) Reflective Practice for Educators: Professional Development to İmprove Student Learning. Corwin Press, Thousand Oaks.

[44] Day, C. (1993) Reflection: A Necessary but Not Sufficient Condition for Professional Development. British Educational Research Journal, 19, 83-93. http://dx.doi.org/10.1080/0141192930190107

[45] Robinson, V., Hohepa, M. and Lloyd, C. (2010) School Leadership and Student Outcomes: Identifying What Works and Why. Ministry of Education, Wellington.

[46] Pont, B., Nusche, D. and Hopkins, D. (2008) Improving School Leadership: Volume 2: Case Studies on System Leadership. OECD, Paris.

[47] Vail, P. (1996) Learning as a Way of Being: Strategies for Survival in a World of Permanent White Water. Jossey-Bass, San Francisco.

[48] Pont, B., Nusche, D. and Hopkins, D. (2008) Improving School Leadership, Volume 2: Case Studies on System Leadership. OECD publishing, Paris. 